\title{
Effect of Packaging Materials on the Chemical and Microbiological Quality of Romi Cheese
}

\author{
Esraa Ahmed Mohammed Abdelmagid ${ }^{1}$ and Omer Ibrahim Ahmed Hamid ${ }^{2 *}$ \\ ${ }^{1}$ Khartoum North, Hillat Hamad \\ ${ }^{2}$ Department of Dairy Science and Technology, College of Animal Production Science and \\ Technology, Sudan University of Science and Technology, Khartoum, Sudan
}

*Corresponding author

\begin{tabular}{|c|}
\hline Keywords \\
\hline $\begin{array}{l}\text { Romi cheese, Microbial } \\
\text { contents, Chemical } \\
\text { composition, Package }\end{array}$ \\
\hline Article Info \\
\hline $\begin{array}{l}\text { Accepted: } \\
22 \text { October } 2018 \\
\text { Available Online: } \\
10 \text { November } 2018\end{array}$ \\
\hline
\end{tabular}

\section{Introduction}

Cheese is a product that made from the curd obtained from milk by coagulating the casein with the help of rennet or similar enzymes in the presence of lactic acid microorganism (Ramakant, 2006). The diversity of cheesemanufacturing protocols, ripening regimens, and composition makes cheese a complex subject microbiologically. Romi cheese is fermented hard cheese manufactured from raw cows and buffalo's milk. As a result of moulds growth mycotoxins may be produced in cheese, rendering it unfit for human consumption (Pitt and Hocking, 2009). Romi cheese has been introduced to Sudanese 
markets very recently, and research concerning them in Sudan is very limited. Cheese packaging is an integral part of processing operations and cheese preservation. Consumers more often directly purchase cheeses in the self-service section of the supermarket, along with other prepackaged fresh produces. It is thus necessary to package products in a way that makes it possible to preserve their quality (Floros et al., 2000).

The study Objective was to determine the effect of packing materials on the chemical composition and microbial contents of Romi cheese.

\section{Materials and Methods}

A total of 60 samples of Romi cheese (30 samples from each of plastic and paper pack) were collected randomly from different area of Khartoum State with different packing materials. The manufacture date of the collected white cheese samples was defined to fixed date for cheese samples. Collected samples were examined for chemical and microbioloical composition under different packing materials.

\section{Chemical analysis}

Chemical composition (fat, protein. total solid, titratable acidity, volatile fatty acids and ash contents) were analysed according to the AOAC (2009). The $\mathrm{Ca}, \mathrm{P}$ and $\mathrm{K}$ were determined according to the Perkin Elmer (1994).

\section{Microbiological analysis of cheese}

Total bacteria count (TBC), Staphylococcus aureus, Coliforms, Escherichia coli, Salmonella and Listeria monocytogens were analysed according to (Harrigan, 1998). Yeast and moulds, analysis was according to Harrigan and McCance (1976).

\section{Statistical analysis}

Statistical analysis was done using SPSS programme (1998). Complete Randamized Design was used to estimate the effect of area and packing materials on the chemical and microbiological quality of Romicheese. Least significant difference tests were used for mean separation between the treatments. The levels of significance $\alpha<0.05$ was used in this study.

\section{Results and Discussion}

Chemical composition of Romi cheese was significantly affected by the packing materials (Table 1). Fat contents of Romi cheese samples in paper pack were higher in comparison with those in plastic pack. The highest value of fat content $(29.40 \pm 1.41 \%)$ was obtained by the sample of Romi cheese on paper pack, the lowest value $(23.31 \pm 1.88 \%)$ found in samples of the Romi cheese in plastic pack. Protein content of Romi cheese was affected significantly $(\mathrm{P}<0.01)$ by the packing materials. The highest value $(25.76 \pm 2.04 \%)$ was found in Romi cheese sample in paper pack, the lowest value $(16.77 \pm 1.26 \%)$ was obtained by Romi cheese samples in plastic pack. Total solids of Romi cheese was affected significantly $(\mathrm{P}<0.001)$ by the packing materials. The highest value $(64.40 \pm 4.12 \%)$ was found in Romi cheese samples in paper pack, the lowest value $(48.86 \pm 2.37 \%)$ of Romi cheeses samples in plastic pack.

Volatile fatty acids of Romi cheese was affected significantly $(\mathrm{P}<0.01)$ by the packing materials. The Romi cheese samples in paper pack had higher VFA content than those in plastic pack. Titratable acidity of Romi cheese was affected significantly $(\mathrm{P}<0.001)$ by the packing materials. The highest value $(0.99 \pm 0.25 \%)$ noted in Romi cheese samples in plastic pack, the lowest value $(0.83 \pm 0.19 \%)$ was found in Romi cheese samples in paper 
pack. Ash content of Romi cheese was affected significantly $(\mathrm{P}<0.01)$ by the packing materials. The highest value $(4.45 \pm 0.80 \%)$ obtained by Romi cheese sample in paper pack, the lowest value $(4.02 \pm 0.47 \%)$ recorded by Romi cheese sample in plastic pack.

Calcium contents of the Romi cheese were affected significantly $(\mathrm{P}<0.01)$ by the packing material. The highest value found in samples of Romi cheese was packed on paper pack than those plastic packs. Romi cheese Phosphorus was affected significantly ( $\mathrm{P}<$ 0.01 ) by the packing material. Phosphorus content of Romi cheese samples on plastic pack higher than those on paper pack. Potassium content of Romi cheese was affected significantly $(\mathrm{P}<0.01)$ by the packing materials. The highest potassium value was found in samples packed in plastic pack, and the lowest one was in samples packed in paper pack.

Table 2 showed that total bacterial counts of Romi cheese were not significantly $(\mathrm{P}>0.05)$ affected by the packing materials. The highest total bacterial count was $(5.43 \pm 0.67 \mathrm{cfu} / \mathrm{ml})$ obtained by samples of Romi cheese in paper pack and the lowest count $(5.37 \pm 0.62 \mathrm{cfu} / \mathrm{ml})$ was noted by samples of the Romi cheese in plastic pack.

Yeast and moulds count was higher in Romi cheese samples in plastic pack compared to that in paper pack (Table 3). Staphylococcus aureus in Romi cheese samples in paper pack was highest than those in plastic pack. Escherichia coli were not detected in Romi cheese samples in plastic pack, while found in paper pack. E. coli was not detected in cheese samples in Khartoum north while found in Khartoum and Omdurman samples. Coliforms were not detected in Romi cheese samples in plastic pack while appeared in cheese samples in paper pack. Salmonella spp and Listeria monocytogens were not detected in Romi cheese samples which might be due to proper hygienic and handling process of cheese. The high fat content of Romi cheese samples in paper pack could be due to the loss of water and the increasing of dry matter. This value was high in compared with (Habib, 2014 and El-Fadal, et al., 2015) who found that fat content of fresh Ras cheese was $(24.05 \%)$ and $(25.89 \%)$.

The higher protein in Romi cheese samples in paper pack may be due to the partial denaturation of soluble proteins by the heat. This value was lower than that by Awad et al., (2014) who studied the chemical composition of Ras cheese and found the Protein content was $(26.78 \%)$ which increased while packing in plastic pack. The low total solids content of Romi cheese samples in plastic pack could be due to the increased action of proteolytic and lipolytic microflora on the cheese components. These values were higher than El-Zahar, (2014) who stated the total solids content of Ras cheese $(47.2 \pm 2.9 \% ; 58.3 \pm 3.8 \%)$. The low VFA of Romi cheese samples in plastic pack could be attributed to utilization of some of VFA by microorganisms. This result disagrees with that by Abdalla et al., (2013) who found the VFA of cheese samples kept in plastic container higher than those in tin container.

Table.2 Total bacterial count of Romi cheese in Khartoum state

\begin{tabular}{|l|l|}
\hline Packing & Total bacterial count(log cfu/ml) \\
\hline Plastic & $5.37 \pm 0.62$ \\
\hline Paper & $5.43 \pm 0.67$ \\
\hline Level of sig. & NS \\
\hline
\end{tabular}

Mean values bearing different superscripts within columns are significantly different $(\mathrm{P}<0.05)$. 
Table.1 The effect of packing materials on the chemical composition of Romi cheese in Khartoum State

\begin{tabular}{|l|c|l|c|c|c|c|c|c|c|c|}
\hline Packing & \multicolumn{2}{|c|}{ Fat \% } & $\begin{array}{l}\text { Crude } \\
\text { protein \% }\end{array}$ & $\begin{array}{c}\text { Total solids } \\
\text { \% }\end{array}$ & $\begin{array}{c}\text { FVA ml } \\
\text { NaoH/100g } \\
\text { cheese }\end{array}$ & $\begin{array}{c}\text { Titra. } \\
\text { acidity \% }\end{array}$ & Ash \% & Ca \% & P \% & K \% \\
\hline Plastic & $23.31 \pm 1.88^{\mathrm{b}}$ & $16.77 \pm 1.26^{\mathrm{b}}$ & $48.86 \pm 2.37^{\mathrm{b}}$ & $6.14 \pm 0.58^{\mathrm{b}}$ & $0.99 \pm 0.25^{\mathrm{a}}$ & $4.02 \pm 0.47^{\mathrm{b}}$ & $0.29 \pm 0.04^{\mathrm{b}}$ & $0.90 \pm .05^{\mathrm{a}}$ & $0.25 \pm 0.06^{\mathrm{a}}$ \\
\hline Paper & $29.40 \pm 1.41^{\mathrm{a}}$ & $25.76 \pm 2.04^{\mathrm{a}}$ & $64.40 \pm 4.12^{\mathrm{a}}$ & $11.42 \pm 1.43^{\mathrm{a}}$ & $0.83 \pm 0.19^{\mathrm{b}}$ & $4.45 \pm 0.80^{\mathrm{a}}$ & $0.85 \pm 0.12^{\mathrm{a}}$ & $0.71 \pm .14^{\mathrm{b}}$ & $0.15 \pm 0.05^{\mathrm{b}}$ \\
\hline Level of sig. & & & & $*_{*}$ & & &
\end{tabular}

Mean values bearing different superscripts within columns are significantly different $(\mathrm{P}<0.05)$.

Table.3 Microbial contents of Romi cheese samples in Khartoum state

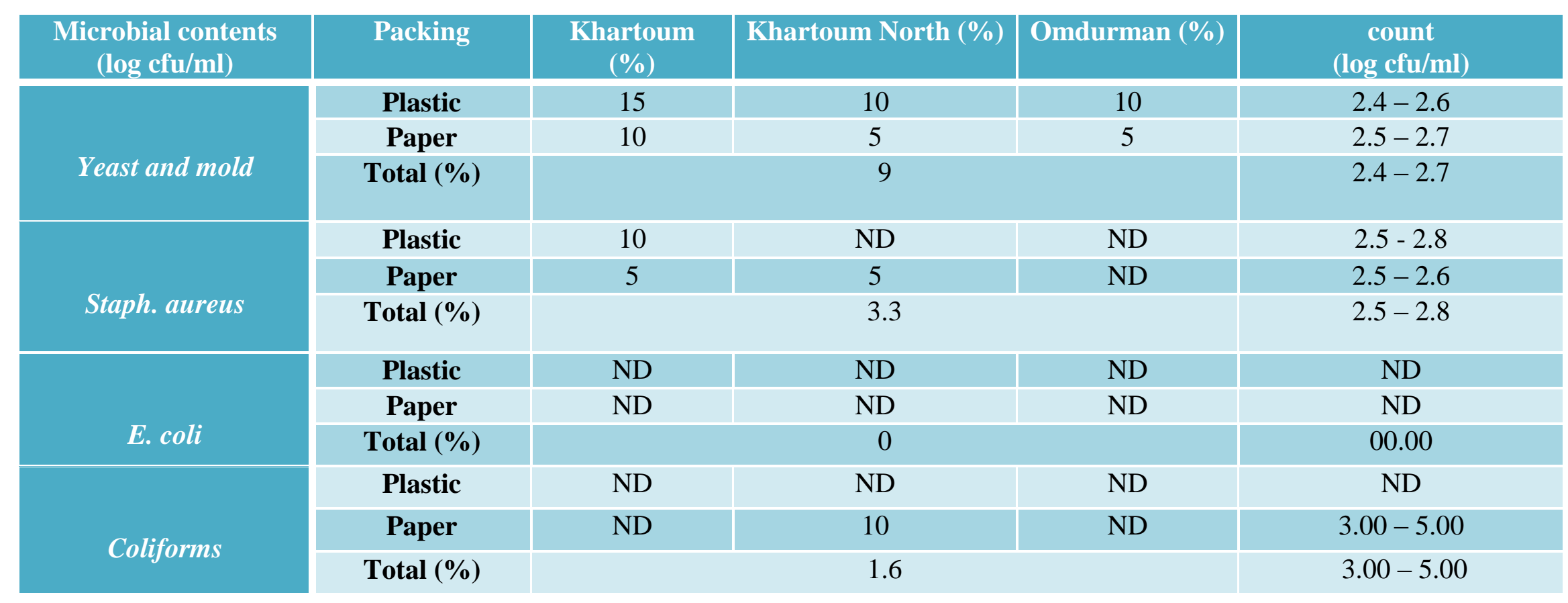


The low acidity of Romi cheese samples in paper pack could be due to the growth of yeasts in cheese. Those values were lower than those by El-Zahar (2014) who found the titratable acidity contents of Ras $(2.2 \pm 0.43 \%$; $1.85 \pm 0.23 \%$ ). The high ash contents of Romi cheese samples in paper pack could be due to the lower moisture content. These values related to those by Mangia et al., (2011). This result disagree with Abdalla et al., (2013) who stated that, the calcium content affected by type of packing and found the higher value for calcium obtained in cheese samples in plastic. The low Calcium contents of Romi cheese samples on plastic pack could be due to the degradation of calcium by cheese microflora. Phosphorus content of Romi cheese samples on plastic pack higher than those on paper pack. Khalid (1991). Abdlla (1992), Nofal et al., (1981) who studied the lower Phosphorous content of Romi cheese samples might be due to the degradation of Phosphorus by microorganisms. The highest potassium value was found in samples packed in plastic pack, and the lowest onewas in samples packed in paper pack. Khalid (1991), Abdalla (1992) Nofal et al., (1981) and Nuser, (2001) who stated the decrease of Potassium contents could be due to the lipolytic activity of microorganisms on Potassium.

The low TBC of Romi cheese sample in paper pack probably due to salting processing. This value lower than that reported by El-Fadaly et al., (2015) who found the total count of bacteria of Ras cheese wheels were $(6.13 \pm 0.18 \quad \log 10 \mathrm{cfu} / \mathrm{g})$ and $(6.12 \pm 0.21$ $\log 10 \mathrm{cfu} / \mathrm{g})$. The high yeast and mold count of Romi cheese samples on plastic pack could be due to presence of oxygen in the plastic pack. That results were not agree with those reported by Hamid, (2005). Yeast and mould were detected in all cheese samples in Khartoum, Khartoum north and Omdurman. The high Staphylococcus aureus count in
Romi cheese samples in paper pack might probably comparable to those by ElNasri et al., (2012) who found that the counts of $S$. aureus showed in the cheese samples packed in plastic containers. The presence of $S$. aureus in Romi cheese samples indicated the poor hygienic conditions and handling (IFST, 1998). Staphylococcus aureus were detected in all cheese samples in Khartoum, Khartoum north and Omdurman. The presence of coliforms in Romi cheese samples, these result were not similar to those of Osman and Abbas (2001) who found that coliforms bacteria were not detected in Ras cheese samples. Coliforms were detected in cheese samples in Khartoum, Khartoum north and Omdurman. Cyelan et al., (1989) expressed that coliforms found in cheese samples might be due to poor environmental and unhygienic conditions of handling. Salmonella and Listeria monocytogens were not detected in all the Romi cheese samples, this result was not agreed with Amran and Abbas (2011) who stated the pathogenic flora such as Salmonella and Listeria were detected in some samples of cheese.

It would be concluded that Romi cheese samples in plastic pack showed higher fat, crude protein, Total solids, FVA, ash, $\mathrm{Ca}$ in comparison with that in paper pack while, lower titratable acidity, $\mathrm{K}$ and $\mathrm{P}$ were recorded for those packed in paper pack. The microbial contents of Romi cheese samples were noted to be higher in plastic container when compared to those in paper pack. E.coli, Salmonella and Listeria monocytogenes were not detected in all Romi cheese samples.

\section{References}

Abdalla, M. I and Hassan, F. A. (2013). Minerals Composition ( $\mathrm{Ca}, \mathrm{Na}, \mathrm{P}$ and Sn) of Sudanese White Soft Cheese International Journal of Scientific and 
Research Publications, Volume 3(5):2250 -3153.

Abdalla, O.M. (1992). Effect of processing conditions on Microbiological quality of white pickled cheese. Ph.D. Dissertation, University of Tennessec. Knoxville, U.S.A.

Amran, A. M. and Abbas A.A. 2011. Microbiological changes and determination of some chemical characteristics for local Yemeni cheese.

Jordan Journal of Biotechnology.4:1076-1079.

Awad, R. A., Salama, W. M., and Farahat, A.M. 2014. Effect of Lupine as Cheese Substitution on Technological and Nutritional Properties of Processed Cheese Analogue. Acta Scientiarum polonorum Technologia Alimentaria, $13,55-64$.

Ceylan, Z.G, Turkgolu, H. and Dayisoylu, S. 2003. The microbiological and chemical quality of Skima cheese produced in Turkey. Pakistan Journal of Nutrition. 2, 95-97.

Dabiza, N and El- Deib, K. 2007. Biochemical evaluation and microbial quality of Ras cheese supplemented with probiotic strains, Polish journal of food and nutrition sciences. vol. 57, no. 3, pp. 295-300.

El- Zahar, K.M. (2014). Biogenic amines and microbiological profile of Egyptian cheeses. African Journal of Science. Vol. 8(3), pp.130-139.

El-Fadaly, H., El-Kadi, S.M., Hamad, M.N.F. and Habib, A. 2015. Isolation and Identification of Egyptian Ras Cheese (Romy) Contaminating Fungi during Ripening Period. Journal of Microbiology Research, 5, 1-10.

ElNasri, N.A., Sirag, S.O. and Elsafi, H.E. 2012. Packaging type and their effects on the chemical and microbial quality of Sudanese white cheese (Gibna bayda). Journal of Toxicology and
Environmental Health Sciences Vol. 4(10), pp. 185-191.

Floros, J. D., Nielsen, P. V., and Farkas, J. K. 2000. Advances in modified atmosphere and active packaging with applications in the dairy industry. Brussels, Belgium: International Dairy Federation. Food and Drugs Board Library, Accra, food. 1-Soft cheese. Egypt. J. Dairy Sci., 30, 217-229.

Habib, A. A. A. 2014. Studies on Fungal Decontamination of Ras Cheese during Storage by Using Some Natural Substances. Master's Thesis, Damietta University, Egypt.

Hamid, O.I.A. 2005. Effect of storage on weight loss, chemical composition, microbiological properties and sensory characteristics of white soft cheese. Ph.D. Thesis, University of Khartoum, Sudan.

Harrigan, and McCance, M. E. 1976. Laboratory Methods in Microbiology. PP.27-3003, Academic Press, London and New York.

Harrigan, W.F. 1998. Laboratory Methods in food microbiology San Diego, London, Boston.3:28-36.

IFST. 1998. Food safety and cheese, Food Science and Technology.12:117-122.

Khalid, EA. 1991. The Effect of Salt Concentration on the Yield and Chemical Composition of Sudanese White Soft Cheese. M.Sc. Thesis, University of Khartoum, Sudan.

Mangia, N. P, Murgia M. A., Garau, G., and Deiana, P. 2011. Microbiological and Physicochemical Properties of PecorinoRomano Cheese Produced Using a Selected Starter Culture. J. Agr. Sci., 13: 585-600.

Nofal, A., Elhami, M., El Gazzar, H. and Abu Elkheir, A. 1981. Studies on acceleration of manufacturing Domati cheese. III Effect of storage on yield and properties of cheese manufactured 
by the suggested method. Agricultural

Research Review, 59: 301-312.

Nuser, S.N.M. 2001. The effect of cooking and vacuum packaging on the quality of white soft cheese. M.Sc. Thesis University of Khartoum, Sudan.

Osman M.M. and Abbas F.M. 2001. Fate of Lactobacillus acidophilus and Bifidobacterium lactis $\mathrm{Bb}-12$ in probiotic Ras cheese. Proceedings of the 8th Egyptian Conf. Dairy Sci. 653-664.

Pitt, J.I. and Hocking, A.D. 2009. Fungi and Food Spoilage, 3rdEdn. London: Blackie Academic and professional.

Ramakant, S. 2006. Production processing and quality of milk and milk product.
International Book Distributing Co. Publishing Division.

SPSS. 1998. SPSS for Windows Version 10. SPSS, Inc., Chicago, Il.

Stadhouders, J., Cordes, M.M. and Van Schoeuwenbergvan Foeken, A.W.J. 1978. The effect of manufacturing conditions on the development of staphytococci in cheese: their inhibition by starter bacteria. Neth. Milk Dairy J. 32: $193-203$

Torkar, G. K. and Teger, G. S. 2004. The microbiological quality of some critical control points in the cheese production of individual Slovenian cheese-makers. Acta. Agri. Slovenica, 84: 43-61.

\section{How to cite this article:}

Esraa Ahmed Mohammed Abdelmagid and Omer Ibrahim Ahmed Hamid. 2018. Effect of Packaging Materials on the Chemical and Microbiological Quality of Romi Cheese. Int.J.Curr.Microbiol.App.Sci. 7(11): 2807-2813. doi: https://doi.org/10.20546/ijcmas.2018.711.323 